\title{
Tuberkuloseutbrudd på Østlandet
}

BAKGRUNN Tuberkulose er en sjelden sykdom i Norge, spesielt blant norskfødte. Smitteoppsporing rundt tilfeller av lungetuberkulose er vesentlig for å finne andre syke og smittede og forhindre nysmitte. I artikkelen beskrives etterforskningen av et utbrudd der mange av de smittede og syke var norske ungdommer.

MATERIALE OG METODE Ni personer med direkte eller indirekte tilknytning til samme utdanningsinstitusjon ble diagnostisert med tuberkulose i 2013. Genetisk testing av tuberkulosebakterier knyttet ytterligere 13 sykdomstilfeller på Østlandet meldt i perioden 2009-13 til utbruddet. For å utforske utbruddet ble det brukt informasjon fra MSIS og i tillegg innhentet informasjon om eksponering og kontaktnett.

RESULTATER Den første pasienten ved utdanningsinstitusjonen hadde symptomer i lang tid før diagnose ble stilt. Smitteoppsporingen rundt dette tilfellet omfattet 319 personer, hvorav åtte var syke, 49 smittet og 37 ble satt på forebyggende behandling. Smitteoppsporingene rundt de øvrige 21 tilfellene varierte i størrelse og omfattet til sammen 313 personer, hvorav to ble funnet syke (inkludert i de 21 tilfellene), 30 var smittet og 12 ble satt på forebyggende behandling.

FORTOLKNING Forsinket diagnose medvirket til et tuberkuloseutbrudd som er uvanlig stort etter norske forhold. Størrelsen på smitteoppsporingene varierte uten åpenbar relasjon til indekspasientens smittsomhet. Utbruddet viser betydningen av fortsatt årvåkenhet overfor tuberkulose som differensialdiagnose, også hos norskfødte.

Mens tuberkuloseforekomsten i verden har sunket i de senere år, har den økt i Norge. Antall tilfeller av tuberkulosesykdom rapportert til Meldingssystem for smittsomme sykdommer (MSIS) har økt fra 201 i 1996 til 401 i 2013 (1). Fremdeles har vi her i landet en av de laveste tuberkuloseforekomstene $\mathrm{i}$ verden, særlig gjelder det norskfødte.

Det antas at bortimot en tredel av alle mennesker i verden er smittet av Mycobacterium tuberculosis, men uten at de er syke og uten at de kan smitte andre (2). Av dem som er smittet, vil bare en liten andel, anslagsvis 5-10\%, utvikle tuberkulosesykdom en gang i løpet av livet, hos omtrent halvparten skjer det de første to årene etter at de ble smittet $(3,4)$. Som indikator for tuberkulosesmitte brukes i Norge IGRA-testen (Interferon-Gamma Release Assay), med eller uten forutgående Mantoux' hudtest (5).

Risikoen for at smittede blir syke av tuberkulose kan reduseres ved forebyggende behandling (3). Positiv IGRA-test sier ikke noe om smittetidspunktet, prøven kan forbli positiv selv etter behandling, og immunsvekkede kan få falskt negativt resultat. De som blir funnet IGRA-positive ved smitteoppsporing, regnes likevel i praksis som nysmittet og tilbys derfor vanligvis forebyggende behandling (5).

Av de 401 tilfellene som ble meldt syke av tuberkulose i Norge i 2013, var 318 (79\%) bekreftet ved dyrking (1). Hver mykobakteriestamme som dyrkes frem, sendes til referanselaboratoriet ved Folkehelseinstituttet, der de resistensbestemmes og undersøkes genetisk. Omtrent tre firedeler av pasientene hadde unike bakteriestammer, stammer som ikke tidligere var funnet i Norge. Det forklares med at de fleste som blir tuberkulosesyke her i landet, ikke er blitt smittet her, men i et høyendemisk fødeland $(1,6)$.

Tuberkulose smitter ved dråpekjerner. I praksis er det bare dyrkingspositiv ubehandlet lungetuberkulose som er smittsom (7). Rundt hvert tilfelle av lungetuberkulose skal kommunens smittevernlege vurdere å igangsette smitteoppsporing. Hva som er riktig omfang, avhenger av indekspasientens smittsomhet og kontaktnett og kontaktenes sårbarhet (7).

Smittsomhet vurderes ved direkte mikroskopi av luftveismateriale. Hvis det ses syrefaste staver (mikroskopipositive), regnes pasienten som «sikkert smittsom», ved dyrkingspositive mikroskopinegative prøver er pasienten «lite smittsom». En røff tommelfingerregel er at de som har vært «i taleavstand» innendørs ( $\mathrm{i}$ en avstand der man uanstrengt kan snakke sammen) i over åtte timer til en som er definert som «sikkert smittsom» eller i over 40 timer til en som er «lite smittsom», er å regne som smitteutsatte kontakter $(5,7)$.

I april 2013 ble det meldt et tilfelle av tuberkulosesykdom hos en student ved en utdanningsinstitusjon på Østlandet. Utdanningen innebærer nær fysisk kontakt og stor fysisk aktivitet over tid. I månedene som fulgte ble åtte av vedkommendes kontakter, hvorav seks studenter ved samme utdanningsinstitusjon, tuberkulosesyke. Ved analyse av bakterie-DNA ble ytterligere 13 tuberkulose-

\author{
Trude Margrete Arnesen \\ trude.arnesen@fhi.no \\ Siri Seterelv \\ Gunnstein Norheim \\ Divisjon for smittevern \\ Nasjonalt folkehelseinstitutt \\ Sigrid Ryg Helgebostad \\ Asker kommune \\ Turid Mannsåker \\ Divisjon for smittevern \\ Nasjonalt folkehelseinstitutt

\section{Ingvild Nesthus Ly \\ Diagnosestasjonen \\ Lungemedisinsk avdeling} \\ Oslo universitetssykehus
}

\section{Else Johanne Rønning \\ Medisinsk avdeling \\ Bærum sykehus}

\section{Tore W. Steen}

Helseetaten

Oslo kommune

Engelsk oversettelse på www.tidsskriftet.no

\section{HOVEDBUDSKAP}

22 sykdomstilfeller av tuberkulose i perioden 2009-13 ble knyttet til ett og samme utbrudd på Østlandet

Forsinket diagnose medvirket til et uvanlig stort tuberkuloseutbrudd

Andelen smittede blant oppgitte kontakter til den første pasienten ved utdanningsinstitusjonen var, som forventet, høyest blant dem som var anslått som mest eksponert

Smitteoppsporing kan være svært ressurskrevende og må målrettes for å nå de mest smitteutsatte 
syke knyttet til det samme utbruddet, som per mai 2014 besto av 22 tilfeller (1).

Formålet med denne artikkelen er å beskrive dette uvanlige tuberkuloseutbruddet $i$ Norge og etterforskningen av det og diskutere hvilke smitteverntiltak som kunne ha hindret det i å bli så stort.

\section{Materiale og metode}

Som ledd i etterforskningen av tuberkuloseutbruddet ble det brukt flere informasjonskilder, både data som rutinemessig meldes og registreres i MSIS og informasjon som ble innhentet spesielt i forbindelse med utbruddshåndteringen fra dem som utførte smitteoppsporingen lokalt.

Folkehelseinstituttet koordinerte utbruddsetterforskningen i samarbeid med kommuneoverleger, kommunalt smittevernpersonell, tuberkulosekoordinatorer, behandlende leger og mikrobiologiske laboratorier. Forhold rundt smitteoppsporingene ble diskutert $\mathrm{i}$ møter, telefonkonferanser og oppfølgende telefonsamtaler.

MSIS inneholder informasjon om hvert tilfelle av meldt tuberkulosesykdom, hver påviste mykobakteriestamme, igangsatt forebyggende behandling og iverksatte smitteoppsporinger. Registeret er basert på meldinger fra klinikere, kommuneleger og laboratorier. Det inneholder ikke informasjon om tuberkulosesmittede som ikke får forebyggende behandling, da positiv IGRA-test alene ikke er meldepliktig.

Fra 2011 har referanselaboratoriet brukt MIRU-VNTR-metoden (mycobacterial interspersed repetitive unit - variable nucleotide tandem repeat) (8) ved genetisk bestemmelse av tilsendte isolater. Bakteriegenomet undersøkes i 24 loci, og funnene gir en «MIRUkode». En klynge (cluster) defineres som prøver fra pasienter med identisk MIRU-kode. Identisk MIRU-kode kan indikere, men ikke bevise, en smittesammenheng (9). Ved utforskning av utbrudd, som her, kan også stammer påvist før 2011 undersøkes med MIRUVNTR-test.

Som inkludert i dette utbruddet regnes tuberkulosesyke meldt til MSIS som enten var dyrkingspositive og hadde lik MIRUkode eller var dyrkingsnegative og derfor ikke hadde MIRU-kode, men ble funnet ved smitteoppsporing rundt et inkludert tilfelle.

Det skal rutinemessig sendes en summarisk rapport til Folkehelseinstituttet om hver smitteoppsporing som blir utført. I forbindelse med utbruddet ved utdanningsinstitusjonen utarbeidet Folkehelseinstituttet i tillegg en kontaktliste (line list) for systematisering og sammenstilling av den informasjonen som smittevernlegen i kommunen normalt ville innhente, men ikke sende til Folkehelseinstituttet, om hver smittekontakt. Kontaktlisten ble sendt til de smittevernlegene

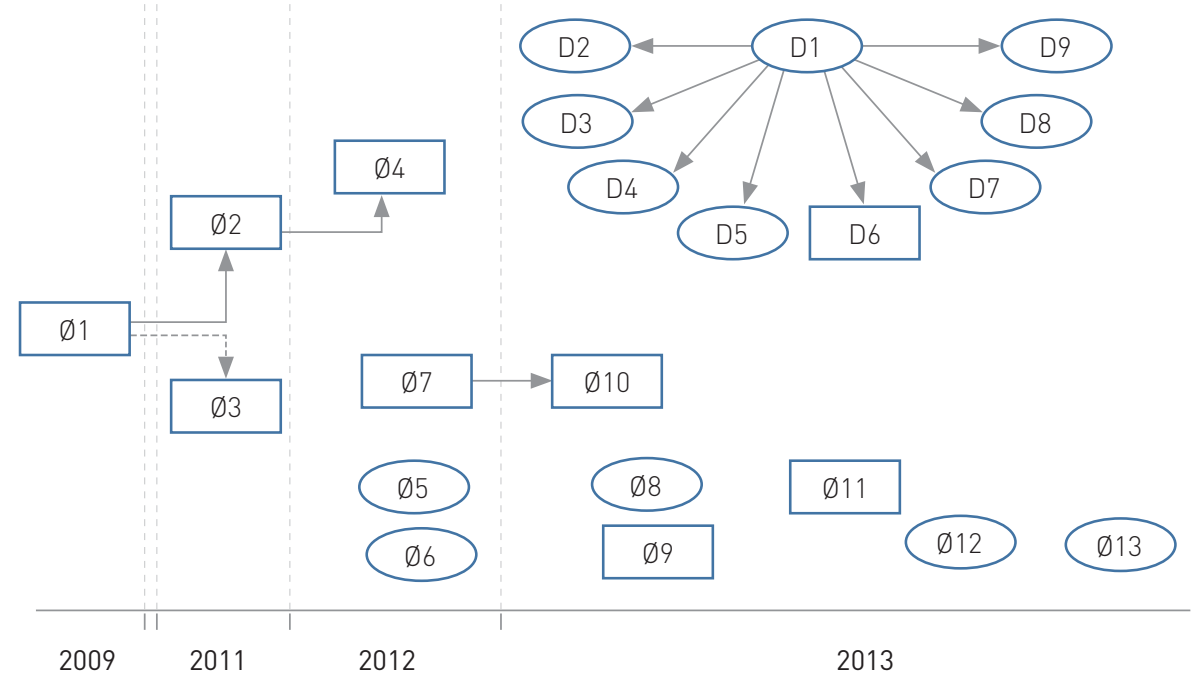

Figur 1 Oversikt over inkluderte tilfeller i utbruddet, etter årstall. D-gruppen: Indekspasienten og hans kon takter. Ø-gruppen: Øvrige pasienter. Pil: Sannsynlig smittekontakt. Rektangel: Foreldre fra høyendemisk land. Oval: Foreldre fra Norge eller lavendemisk land

som var ansvarlige for smitteoppsporingene lokalt. Legene kunne velge om de fant det hensiktsmessig å ta den i bruk. I tilfeller der smitteoppsporingen allerede var fullført, ble kontaktlisten stort sett ikke utfylt.

I kontaktlisten var det rubrikker for nedtegning av hver smittekontakts relasjon til den syke, resultater fra Mantoux' prøve, IGRA-test og lungerøntgen samt konklusjon på undersøkelsen. Undersøkeren ble også bedt om å anslå omtrentlig eksponeringstid i taleavstand til den syke i perioden han hadde symptomer i en av seks kategorier: under ca. 8 timer (ikke smitteutsatt), ca. 8-39 timer (tilfeldig kontakt), ca 40-99 timer (etablert kontakt), ca. 100-250 timer (nærkontakt /husholdningskontakt) eller $>250$ timer (spesielt nær kontakt).

I denne artikkelen er friske kontaktpersoner definert som «smittet» hvis IGRA-testen var positiv, som «ikke smittet» dersom Mantoux' test eller IGRA-test var negativ minst åtte uker etter siste kjente eksponering og som «ikke konkludert» dersom positiv Mantoux' prøve ikke var bekreftet med IGRAtest eller det ikke forelå adekvate prøvesvar.

Regional etisk komité ble forelagt utbruddsetterforskingen og vurderte at egen søknad ikke var nødvendig. Samtykke til publisering av pasienthistorien fra den første som fikk tuberkulose ved utdanningsinstitusjonen (D1) er innhentet. Personvernombudet ved Folkehelseinstituttet ble forelagt artikkelen og hadde ingen innvendinger.

\section{Resultater}

Utdanningsinstitusjonstilknyttet

del av utbruddet

En ung, sosialt aktiv mann (D1) som har vokst opp i en norsk familie i Norge, hadde hostet $\mathrm{i}$ to år og hanglet $\mathrm{i}$ ett, men hadde klart å følge sin fysisk krevende fulltidsutdanning. Han anga at han hadde oppsøkt ulike leger, fătt ulike diagnoser og var blitt behandlet med astmamedisin og hostedempende og hadde fått råd om røykeslutt. Lungerøntgen tatt 14 måneder før diagnosetidspunkt var negativ. Da han ble akuttinnlagt med spørsmål om lungetuberkulose, var han febril, hadde gått ned 20 kilo, svettet om natten og hostet opp blod. Lungerøntgen viste kaverner, og direkte mikroskopi av sputum viste rikelig med syrefaste staver. Dette tydet på at han var sikkert smittsom og at han sannsynligvis hadde vært det $\mathrm{i}$ lang tid.

I løpet av ni måneder i 2013 ble åtte av hans kontakter, heretter kalt D2-D9, syke av tuberkulose (fig 1). D2-D6 ble innlagt i løpet av en måneds tid. I annen halvdel av året fikk ytterligere tre kontakter ved institusjonen (D7-D9) påvist tuberkulosesykdom. Disse var allerede blitt identifisert som smittet, og det var planlagt forebyggende behandling. Lik MIRU-kode som hos D1 ble påvist hos alle, unntatt hos den ene der bakteriologisk prøve ikke ble tatt.

Medregnet D1 var sju av de syke studenter ved samme utdanningsinstitusjon. Gjennomsnittsalderen til de ni var 21 år, median alder var 22 år. Det var seks kvinner. Åtte av ni hadde vokst opp i Norge med norske foreldre.

\section{$\emptyset$ vrige tilfeller knyttet til utbruddet gjennom DNA-analyser}

Samme MIRU-kode som for åtte av pasientene i gruppen D1-D9 ble også påvist hos 12 andre pasienter fra Østlandet. Stammene tilhørte Beijing-familien av M. tuberculosis. Et 13. tilfelle, der prøven var dyrkingsnega- 


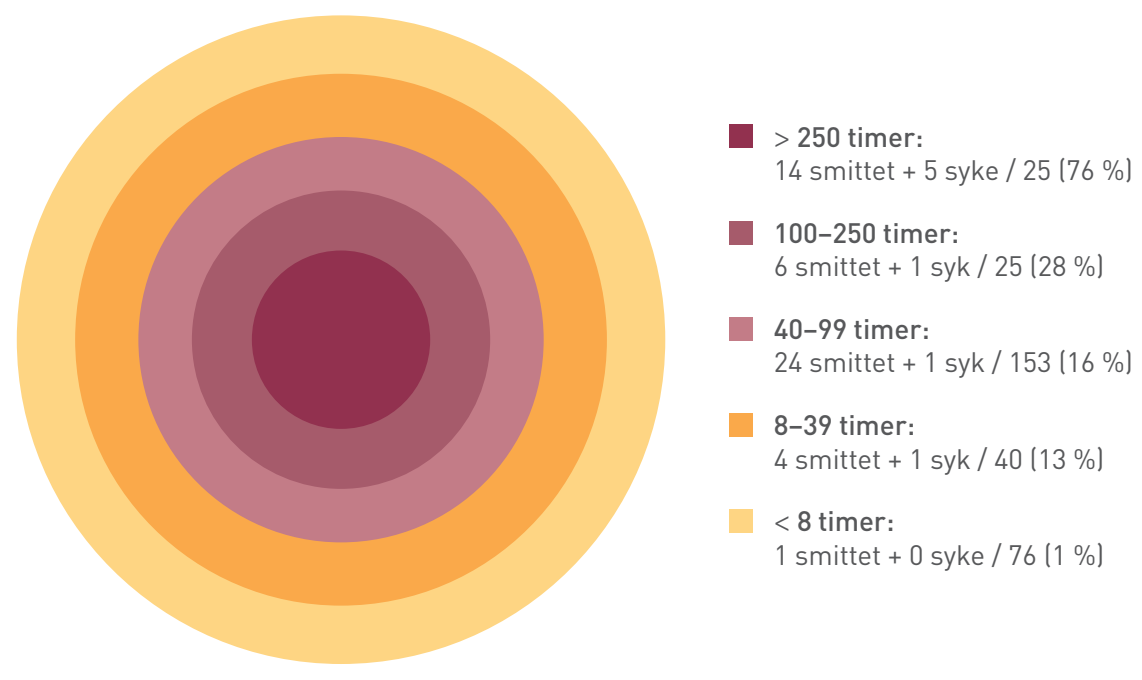

Figur 2 Andel smittede og syke (\%) funnet i smitteoppsporingen rundt det første tuberkulosetilfellet ved utdanningsinstitusjonen, etter anslått eksponeringstid. For 34 av de 319 undersøkte var smittestatus ikke konkludert

tiv og dermed manglet MIRU-kode, ble inkludert fordi vedkommende var funnet ved smitteoppsporing rundt én av de inkluderte. Disse 13 kalles heretter Ø1-Ø13.

Det første tilfellet (Ø1) ble meldt i 2009, Ø2-Ø3 ble meldt i 2011, Ø4-Ø7 i 2012 og Ø8-Ø13 ble meldt i 2013 (fig 1). Gjennomsnittsalderen for de 13 var 35 år, median alder 30 år. Åtte av de 13 var født utenfor Norge, $\mathrm{i}$ fem forskjellige fødeland.

Ø1-Ø4 hadde bakgrunn fra samme land og bodde i samme område på Østlandet samtidig. For ett av disse tilfellene var det ikke avdekket kjent kontakt med noen av de tre andre tilfellene. For å sjekke ut om funn av samme bakteriestamme avspeilte at dette er en vanlig stamme i landet de kom fra, ble resistensmønster for alle tuberkulosetilfeller meldt med samme landbakgrunn som Ø1-Ø4 siden 2001 sammenholdt. Fem hadde samme resistensmønster som den aktuelle stammen, men ingen av de fem hadde den aktuelle MIRU-VNTR-koden.

$\varnothing 7$ og Ø10 var nære bekjente. For de resterende sju ble det ikke avdekket noen kjent kontakt utover at alle hadde oppholdt seg i et begrenset område på Østlandet og at alle ble diagnostisert i løpet av 2012 og 2013.

Seks av de 13 ble meldt av kliniker til MSIS som antatt smittet i utlandet, fem som smittet i Norge og to med ukjent smitteland.

Av til sammen 22 syke var 16 BCG-vaksinert (registrert i SYSVAK, hadde synlig arr eller ble antatt vaksinert pga. alder og oppvekst i Norge), mens de øvrige seks hadde ukjent vaksinasjonsstatus.

\section{Smitteoppsporingen rundt D1}

Smitteoppsporingen rundt D1 ble raskt igangsatt og bredt anlagt. Ansvarlig smitte- vernlege valgte å fylle ut tilsendt kontaktliste systematisk fra helt fra starten av.

De nærmeste kontaktene (fra samme husholdning eller klasse) ble undersøkt samme uke med røntgen thorax og IGRA-test. Øvrige studenter ved skolen ble raskt informert og tilbudt en første undersøkelse med Mantoux' test i utdanningsinstitusjonens lokaler. Ved positivt resultat ble det utført IGRA-test, og dersom denne var positiv, ble vedkommende henvist med tanke på forebyggende behandling. Ved negativ prøve ble den gjentatt åtte uker etter siste smitteeksponering. De som ikke møtte, ble purret per brev eller telefon.

I alt ble 319 kontakter rundt D1 undersøkt (fig 2). Det ble funnet til sammen åtte syke og 49 smittede, hvorav 37 (75\%) fikk forebyggende behandling. 34 kontakter som hadde fått tatt den første Mantoux-testen, hvorav 15 der denne var positiv, fikk ikke tatt IGRA-test eller en ny Mantoux-test etter minst åtte uker etter siste kontakt, og smittestatus ble derfor ikke konkludert.

Andelen smittede og syke samvarierte med anslått eksponeringstid (fig 2), fra 19 av 25 $(76 \%)$ hos kontakter med eksponeringstid over ca. 250 timer til én av $76(1 \%)$ hos kontakter med eksponeringstid under åtte timer. Fem av de åtte kontaktene som per mai 2014 var blitt syke, var i kategorien mest eksponert.

\section{Smitteoppsporingene}

\section{rundt de 21 andre tilfellene}

Smitteoppsporingene rundt de øvrige 21 tilfellene omfattet til sammen 313 personer, hvorav 30 var smittet. 12 av disse $(40 \%)$ var satt på forebyggende behandling.

Av tilfellene D2-D9 var det fem som hadde lungetuberkulose. Kun én av disse var sikkert smittsom (direkte mikroskopi-positiv), tre var lite smittsomme (dyrkingspositive, mikroskopinegative), og for én var mikroskopi ikke utført. Tre hadde tuberkulose utenfor lungene (i pleura) og var ikke smittsomme. Smitteoppsporingene rundt D2-D9 inkluderte mellom to og 26 kontakter (fig 3). Til sammen ble 89 undersøkt, hvorav fem var smittet og ingen var syke.

Av de 13 tilfellene Ø1-Ø13 hadde 11 dyrkingspositiv lungetuberkulose. Åtte var mikroskopipositive, det vil si at de var sikkert smittsomme. Smitteoppsporingene rundt disse åtte inkluderte fra 109 til ingen personer, fire av oppsporingene besto av færre enn fire kontakter (fig 3). Det første tilfellet (Ø1) ble identifisert i 2009 ved rutinemessig ankomstundersøkelse av innvandrere. Smitteoppsporingen rundt vedkommende omfattet tre personer og fanget ikke opp Ø2, som senere oppga å ha vært i kontakt med Ø1.

Rundt $\varnothing 7$ ble det undersøkt 28 kontakter, og en av dem viste seg å ha tuberkulose (Ø10).

Ved telefonisk oppfølging av de ansvarlige for hver smitteoppsporing, og gjennom telefonkonferanser for å koordinere dem, fremkom det at flere av smitteoppsporingene, spesielt rundt Ø-tilfellene var svært vanskelige å gjennomføre. Dette skyldtes dels at de syke ikke ville gi informasjon om sine kontakter, dels at kontaktene ikke kunne gjenfinnes og dels at de innkalte ikke møtte til kontroll. I enkelte av smitteoppsporingene, særlig rundt D-tilfeller, hadde man det motsatte problemet - flere enn det var medisinsk grunn til å undersøke ville bli undersøkt.

\section{Diskusjon}

Vi har beskrevet et utbrudd bestående av ni tilfeller av tuberkulosesykdom med kjent smittekontakt og 13 andre sykdomstilfeller som vi antar har tilknytning til disse. Samlet sett ble 632 personer undersøkt som ledd i smitteoppsporingene rundt de 22 tuberkulosesyke, ti syke ble funnet gjennom smitteoppsporingene (inkludert i de 22) og 79 ble funnet smittet. Utbruddet er uvanlig stort etter norske forhold.

\section{Samme utbrudd?}

Antakelsen om at Ø1-Ø13 tilhører samme utbrudd som D1-D9, er gjort på grunnlag av at de alle hadde bodd i samme by på Østlandet samtidig og at deres bakteriestammer (der den kunne dyrkes frem) hadde lik MIRU-kode. Til sammenlikning er de fleste bakteriestammene som påvises i Norge bare påvist hos én enkelt tuberkulosesyk $(1,6)$.

Smittesammenhengen kan ikke påvises ved MIRU-VNTR-metoden, sammenheng kan bare avvises ved ulik bakteriestamme eller sannsynliggjøres når den holdes opp mot epidemiologisk informasjon (9). Ø1-Ø4 kom fra samme land - en alternativ forkla- 
ring er at de er blitt smittet av samme stamme der eller på vei til Norge. Ø2 oppga imidlertid å ha vært i kontakt med Ø1 etter ankomst til Norge, hvilket gjør dette til et mer sannsynlig smittested. De øvrige personene har til sammen fem ulike fødeland, slik at det er vanskelig å se for seg et mer sannsynlig felles smittested enn Østlandet, der de alle oppholdt seg i samme periode.

Basert på sykehistorien er det sannsynlig at pasient D1 smittet sine kontakter ved skolen og ikke omvendt, og at pasienten ble smittet av et av de tidligere tilfellene av lungetuberkulose. Planlagt helgenomsekvensering vil kunne gi ytterligere informasjon om smittevei.

Flere av de utenlandsfødte var blitt meldt som smittet utenfor Norge, mens utbruddsetterforskningen i ettertid har sannsynliggjort at de ble smittet her i landet. Dette er en påminnelse om at også personer som kommer fra eller har oppholdt seg i høyendemiske land kan være smittet i Norge.

\section{Sammenheng}

mellom eksponering og smitte

I den store smitteoppsporingen rundt D1 ble den enkelte kontakts eksponeringstid systematisk anslått til en av fem kategorier. I smitteoppsporingen rundt de øvrige 21 tilfellene er det forskjell på hvordan eksponeringsgraden er angitt, eller den er ikke angitt. Vi legger derfor størst vekt på det som ble funnet rundt D1.

I kategorien «spesielt nær kontakt» - der det ble anslått at de hadde tilbrakt over 250 timer i taleavstand til den smittsomme - var tre firedeler $(76 \%)$ enten smittet eller syke. I kategorien «øvrige nærkontakter» var andelen smittede og/eller syke $28 \%$, deretter $16 \%$ og så $13 \%$. Av de undersøkte som hadde vært sammen med D1 i under åtte timer, som etter gjeldende retningslinjer vanligvis ikke vil bli inkludert i en smitteoppsporing, var bare én av 76, altså i overkant av $1 \%$, smittet. Vi kjenner ikke andelen smittede i normalbefolkningen i Norge, men gitt at WHO anslår at en tredel av verdens befolkning er smittet (2), er andelen smittede i den norske befolkningen mest sannsynlig godt over $1 \%$.

Disse funnene er i tråd med funnene i en annen norsk undersøkelse (10) og med gjeldende råd om at personer med eksponeringstid på under åtte timer vanligvis er svært lite smitteutsatt (5). Funnene vil imidlertid kunne være påvirket av usikkerhet rundt anslått eksponeringstid og varierende omfang av smitteoppsporing rundt den enkelte.

Mer uvanlig var den store andelen nære kontakter av de smitteoppsporede som var blir smittet. Til sammenlikning ble det i en metaanalyse av 108 publiserte smitteoppsporinger fra høyinntektsland funnet gjennomsnittlig 3,1\% syke blant husholdnings-

Antall undersøkte

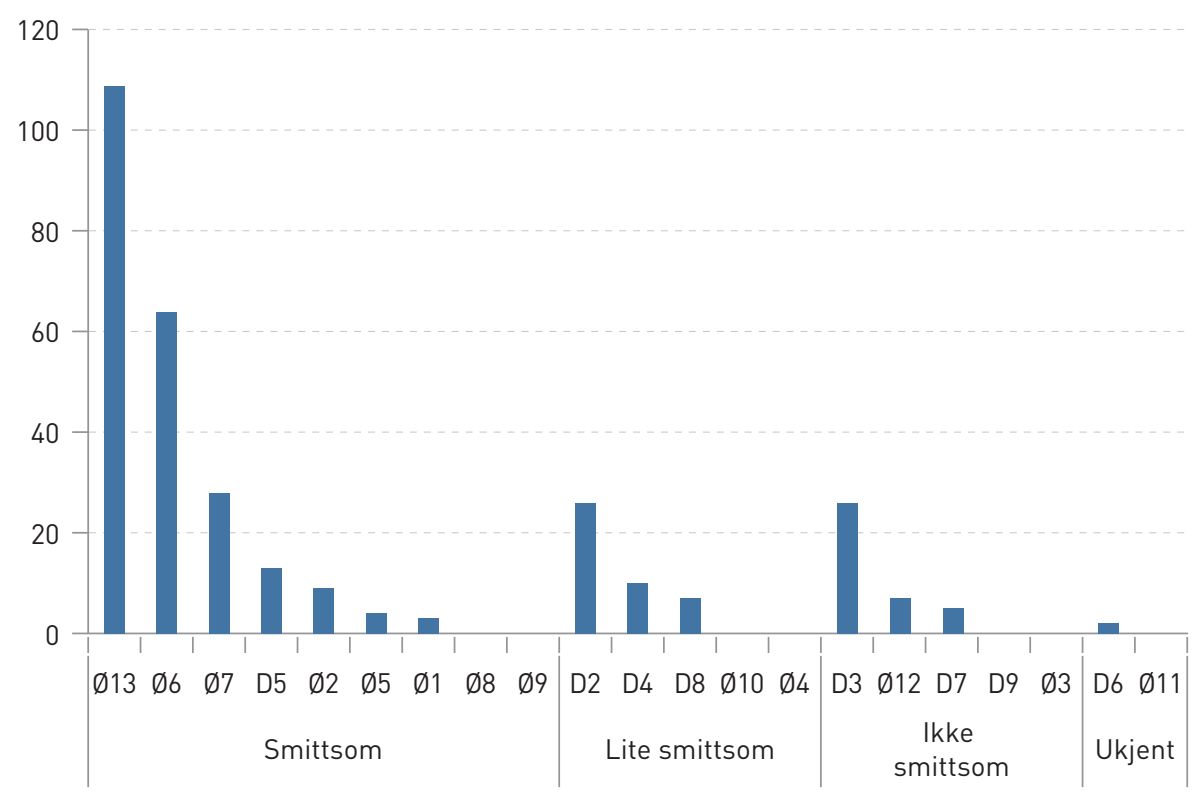

Figur 3 Antall undersøkte i hver smitteoppsporing i forhold til smittsomheten hos indekspasienten. D-gruppen: Indekspasienten og hans kontakter. Ø-gruppen: Øvrige pasienter

kontakter (11). Det er derfor naturlig å spørre om det var noe spesielt ved sykehistorien til D1, forholdene ved utdanningsinstitusjonen eller ved bakterien som fremmet smittespredning.

\section{Hvorfor ble utbruddet så stort?}

Den viktigste enkeltfaktoren som medvirket til at utbruddet ble så stort, var antakelig forsinket diagnose av D1. Tiden det tar fra symptomdebut til diagnose og behandlingsstart har avgjørende betydning for smittespredningen, uavhengig av om det er pasienten eller helsevesenet som forsinker (7). I dette tilfellet ble det ikke undersøkt for tuberkulose, til tross for langvarige og kraftige luftveissymptomer og flere legebesøk.

Videre kan egenskaper ved tuberkulosebakterien ha hatt betydning. Den aktuelle tuberkulosestammen var av Beijing-familien, som kan ha økt virulens (12).

I tillegg kan forhold ved omgivelsene ha medvirket (7). Konsentrasjonen av dråpekjerner er avhengig av luftvolumet de fordeles i. I utdanningsinstitusjonens daværende lokaler var det lav takhøyde og begrenset ventilasjon og utluftning, slik at luftvolumet var relativt lite.

Utdanningens egenart kan også ha spilt inn. Stor fysisk aktivitet medfører inhalasjon av større luftvolum, og nær fysisk kontakt med smittekilden medfører høyere konsentrasjon av dråpekjerner i luften som pustes inn.

\section{Leter vi der vi bør?}

Hvorvidt det bør gjøres en smitteoppsporing og hvor bredt den eventuelt skal anlegges, avhenger av flere faktorer. Mest avgjørende er det hvor smittsom indekspasienten er.

I figur 3 ses ingen tydelig sammenheng mellom de 22 tilfellenes grad av smittsomhet og størrelsen på smitteoppsporingene rundt dem. Det ble for eksempel undersøkt fire eller færre kontakter rundt fire klart smittsomme Ø-tilfeller, mens det ble undersøkt 26 kontakter rundt ett D-tilfelle som ikke var smittsomt. At vi ikke ser noen tydelig sammenheng, kan også skyldes ulik størrelse på kontaktnettene.

Spesielt interessant er det å merke seg at $\varnothing 2$ hadde oppgitt $\varnothing 1$ som kontakt, men ikke selv var fanget opp i smitteoppsporingen rundt $\varnothing 1$. Av figur 1 ser man at utbruddet kanskje kunne vært unngått dersom man i smitteoppsporingen rundt $\varnothing 1$ hadde lyktes i å finne alle smittede og disse hadde fått forebyggende behandling før de ble syke.

Smitteoppsporingene rundt D-tilfellene i dette materialet foregikk i stor grad i ressurssterke og velintegrerte miljøer, mens miljøene rundt $\varnothing$-tilfellene var mer varierte og til dels ressurssvake eller løst tilknyttet det norske samfunnet.

Smittevernpersonellet som var involvert i gjennomføringen av de ulike smitteoppsporingene, hadde ulike erfaringer. Noen rapporterte at arbeidet var svært utfordrende. Særlig gjaldt dette smitteoppsporingene rundt noen av $\varnothing$-tilfellene. I flere av disse miljøene var det mange nyankomne til landet, det var liten tillit til helsevesenet, noen hadde ikke fast bopel, leste ikke norsk eller møtte av andre grunner ikke opp på riktig sted til riktig tid, selv etter flere forsøk på 
å få kontakt og formidle informasjon. Å nå frem til dem som ikke ønsker å bli undersøkt, kan være svært ressurskrevende eller ikke praktisk mulig.

Et tilleggsmoment som kan forsterke forskjellen mellom miljøene, er at undersøkelse for latent tuberkulose forutsetter til dels betydelig innsats av den som skal undersøkes. Frem til oktober 2014 ble det krevd Mantoux' test før IGRA-test, hvilket innebar at pasienten måtte møte frem tre ganger for at tuberkulosesmitte skulle bli diagnostisert. I tillegg kommer oppmøte til lungerøntgen og eventuelt poliklinisk undersøkelse. I dette materialet ser vi at selv med imponerende innsats i ressurssterke miljøer rundt D1, var det 34 som fikk satt Mantoux-test, men ikke en ny test etter minst åtte uker etter siste kontakt eller en konkluderende IGRA-test. Vi antar at hvis IGRA-test var den eneste, vil dette kunne gjøre undersøkelsen lettere å gjennomføre.

Forebyggende behandling og vaksinasjon Risikoen for at latent tuberkulose skal utvikles til tuberkulosesykdom er størst rett etter eksponering. Samtidig er det viktig at tuberkulosesykdom er utelukket før oppstart av forebyggende behandling.

I dette materialet var tre av dem som ble syke allerede diagnostisert med latent tuberkulose, men hadde av ulike årsaker ikke startet med forebyggende behandling. Dette kan tjene som argument for betydningen av rask vurdering av forebyggende behandling ved nysmitte.

BCG-vaksinering ble tatt ut av vaksinasjonsprogrammet i 2008/09. Denne endringen kom etter at de fleste inkluderte i dette utbruddet allerede hadde fått vaksinen.

\section{Konklusjon}

Forsinket diagnose medvirket til et uvanlig utbrudd av tuberkulose hos ni unge mennesker på Østlandet i 2013, hvorav sju var studenter ved den samme utdanningsinstitusjonen. Vi fant som forventet sammenheng mellom eksponeringskategori og antall smittede og syke blant oppgitte kontakter til den første pasienten ved utdanningsinstitusjonen. Ytterligere 13 tuberkulosesyke på Østlandet i perioden 2009-13 regnes som tilhørende det samme utbruddet. Den første av disse ble funnet ved rutinemessig undersøkelse av innvandrere.

Smitteoppsporingenes omfang reflekterte i varierende grad indekspasientenes smittsomhet. Dette kan skyldes ulike kontaktnett, forskjeller i oppmøte til undersøkelse i miljøene der smitteoppsporingen gjøres eller forskjell i innsats fra smittevernpersonellet $\mathrm{i}$ kommunen.

Av dem som ble undersøkt for latent tuberkulose, var det flere som ikke fikk noe svar på om de var smittet. Vi antar at forenklet diagnostikk av latent tuberkulose kan bidra til bedre oppslutning om undersøkelsen.

Vi takker Ingunn Haakerud, Henriette Egebakken, Janne Oseberg Rønning, Camilla Rytterager Ingvaldsen, Hege S. Bjelkarøy og Irene Teslo for at de bisto med diskusjoner, datainnsamling og analyse av prøver i innledende fase, og Brita Winje, Bernardo Guzman, Einar Heldal og Karin Rønning for at de leste gjennom og hadde viktige kommentarer til manuskriptet.

\section{Trude Arnesen (f. 1967)}

er dr.med., spesialist i samfunnsmedisin og har en mastergrad i public health. Hun er overlege og leder for Folkehelseinstituttets tuberkuloseprogram.

Forfatter har fylt ut ICMJE-skjemaet og oppgir ingen interessekonflikter.

\section{Siri Seterelv (f. 1975)}

er lege i spesialisering i samfunnsmedisin og arbeider med infeksjonsovervåking.

Forfatter har fylt ut ICMJE-skjemaet og oppgir ingen interessekonflikter.

\section{Gunnstein Norheim (f. 1975)}

er cand.pharm., ph.d. og forsker ved nasjonalt referanselaboratorium for mykobakterier.

Forfatter har fylt ut ICMJE-skjemaet og oppgir ingen interessekonflikter.

\section{Sigrid Ryg Helgebostad (f. 1953)}

er lege i spesialisering i samfunnsmedisin og smittevernlege i Asker.

Forfatter har fylt ut ICMJE-skjemaet og oppgir ingen interessekonflikter.

\section{Turid Mannsåker (f. 1946)}

er spesialist i medisinsk mikrobiologi og har vært leder for nasjonalt referanselaboratorium for mykobakterier ved Folkehelseinstituttet. Forfatter har fylt ut ICMJE-skjemaet og oppgir ingen interessekonflikter.

\section{Ingvild Nesthus Ly (f. 1946)}

er overlege og seksjonsleder.

Forfatter har fylt ut ICMJE-skjemaet og oppgir ingen interessekonflikter.

\section{Else Johanne Rønning (f. 1962)}

er seksjonsoverlege ved infeksjonsmedisinsk seksjon.

Forfatter har fylt ut ICMJE-skjemaet og oppgir ingen interessekonflikter.

\section{Tore W. Steen (f. 1950)}

er dr.med., spesialist i samfunnsmedisin og smittevernoverlege.

Forfatter har fylt ut ICMJE-skjemaet og oppgir

ingen interessekonflikter.
Litteratur

1. Arnesen TM, Eide $K \AA ̊$, Norheim $G$ et al. Tuberkulose i Norge 2013 - med behandlingsresultater for 2012. Oslo: Folkehelseinstituttet, 2014.

2. World Health Organisation. (2014). Tuberculosis. Fact sheet 104. www.who.int/mediacentre/ factsheets/fs104/en/ (20.3.2014)

3. Centers for Disease Prevention and Control. Fact Sheets - Latent TB Infection vs. TB Disease. www.cdc.gov/tb/publications/factsheets/general/ ltbiandactivetb.htm (1.5.2014).

4. Comstock GW, Livesay VT, Woolpert SF. The prognosis of a positive tuberculin reaction in childhood and adolescence. Am J Epidemiol 1974; 99: 131-8.

5. Folkehelseinstituttet. Tuberkuloseveilederen www.fhi.no/publikasjoner-og-haandboker/ tuberkuloseveilederen (1.5.2014)

6. Dahle UR, Eldholm V, Winje BA et al. Impact of immigration on the molecular epidemiology of Mycobacterium tuberculosis in a low-incidence country. Am J Respir Crit Care Med 2007; 176: 930-5.

7. Erkens CG, Kamphorst M, Abubakar I et al. Tuberculosis contact investigation in low prevalence countries: a European consensus. Eur Respir J 2010: 36: 925-49.

8. Supply P, Allix C, Lesjean S et al. Proposal for standardization of optimized mycobacterial interspersed repetitive unit-variable-number tandem repeat typing of Mycobacterium tuberculosis. J Clin Microbiol 2006; 44: 4498-510.

9. Mears J, Vynnycky E, Lord J et al. The prospective evaluation of the TB strain typing service in England: a mixed methods study. Thorax 2015. E-publisert 16.4

10. Døllner H, Ramm CT, Harstad I et al. Risk of developing tuberculosis after brief exposure in Norwegian children; results of a contact investigation. BMJ open 2012; 2: 6 e001816.

11. Fox GJ, Barry SE, Britton WJ et al. Contact investigation for tuberculosis: a systematic review and meta-analysis. Eur Respir J 2013; 41: 140-56.

12. Hanekom M, Gey van Pittius NC, McEvoy C et al. Mycobacterium tuberculosis Beijing genotype: a template for success. Tuberculosis (Edinb) 2011; 91: $510-23$

Mottatt 11.6. 2014, første revisjon innsendt 19.12 . 2014, godkjent19.10. 2015. Redaktør: Siri Lunde Strømme. 